\title{
Developing a scientific culture through supervision
}

Author:
Danie F.M. Strauss ${ }^{1}$
Affiliation:
'Department of
Philosophy, University of the
Free State, South Africa
Correspondence to:
Danie Strauss
Email:
dfms@cknet.co.za
Postal dates:
PO Box 339, Bloemfontein
9300, South Africa
Dates:
Received: 11 Mar. 2011
Accepted: 29 Sept. 2011
Received: 14 Dec. 2012
How to cite this article:
Strauss, D.F.M., 2012,
'Developing a scientific
culture through supervision',
Koers - Bulletin for Christian
Scholarship 77(2), Art. \#57,
11 pages. http://dx.doi.
org/10.4102/koers.v77i2.57

(C) 2012. The Authors. Licensee: AOSIS OpenJournals. This work is licensed under the Creative Commons Attribution License.
Through effective educational transmission cultural traditions are passed on to subsequent generations. The presence of alternative theoretical views of reality (paradigms) in various academic disciplines uprooted the positivistic conviction that genuine science ought to be 'objective' and 'neutral'. The background of this view is found in Renaissance and postRenaissance philosophy, with its initial points of culmination in the thought of the 18th century philosopher, Immanuel Kant. He safe-guarded autonomous human freedom by restricting scholarship to phenomena (subject to the universal law of causality). The dialectic between nature and freedom gave direction to modern philosophy. Non-reductionist orientations eventually emerged recognising what is irreducible. Although a sound academic culture, operative within supervision to doctoral students, must pay attention to argumentative skills and informal logic, it must at the same time acknowledge the limitations of logic. The principle of sufficient reason refers human thinking beyond logic itself. The supervisor therefore should generate, amongst students, an awareness of the difference between reductionist and non-reductionist ontologies. Doctoral students must also realise that persistent themes and scientific revolutions go hand-in-hand. Some examples of seeing the aspects of reality as modes of explanation are given, before the seven aims of scientific endeavors identified by Stafleu are stipulated. This constitutes another important guideline that ought to be taken into account in supervising post-graduate work. Argumentative skills, scientific communication and the status of facts are discussed before a concluding formulation is given in which the overall argument of the article is summarised.

Die ontwikkeling van 'n akademiese kultuur deur middel van studieleiding. Deur middel van effektiewe opvoedkundige oordrag word kulturele tradisies deurgegee aan opeenvolgende geslagte. Die teenwoordigheid van alternatiewe teoretiese siening van die werklikheid (paradigmas) in verskillende vakgebiede het die positivistiese oortuiging dat 'egte' wetenskap 'objektief' en 'neutraal' is, ontwortel. Die agtergrond van hierdie seining gryp terug na die Renaissance en post-Renaissance filosofie wat sy aanvanklike kulminasiepunt in die denke van die 18de eeuse filosoof, Immanuel Kant, sou beleef. Hy wou die mens se outonome vryheid beveilig deur wetenskaplike denke tot verskynsels te beperk (onderworpe aan die universele kousaliteitswet). Die dialektiek tussen natuur en vryheid was rigtinggewend vir die moderne filosofie. Eventueel het nie-reduksionistiese oriëntasies verskyn wat erkenning verleen het aan dit wat onherleibaar is. Alhoewel 'n gesonde akademiese kultuur, wat in swang is by die begeleiding van doktorsgraadstudente, aandag moet gee aan argumentatiewe vaardighede en informele logika, moet dit tegelyk ook erkenning verleen aan die beperkinge van die logika. Die beginsel van toereikende grond verwys die menslike denke immers na dit wat die logika te bowe gaan. Die studiebegeleider moet daarom by die student 'n besef laat ontwikkel van wat die verskil tussen reduksionistiese en nie-reduksionistiese ontologieë is. Doktoraalstudente moet ook daarmee rekening hou dat duursame temas en wetenskaplike revolusies hand-aanhand gaan. Voorbeelde van hoe die aspekte van die werklikheid as verklaringsmodi gesien kan word is gegee alvorens die sewe doestellinge van wetenskaplik-besig-wees, soos deur Stafleu geïdentifiseer, aangestip is. Dit beliggaam nog ' $n$ ander riglyn wat verreken behoort te word by die begeleiding van nagraadse werk. Daarom word argumentatiewe vaardighede, kommunikasie en die status van feite bespreek alvorens die hele artikel opgesom word in 'n samevattende formulering van die oorkoepelende argument.

\section{Orientation}

Supervision is the key element in transferring an academic culture of teaching, research and scholarly communication to subsequent generations - and in doing that both the university and the surrounding community benefit from this basic academic practice. Ultimately five interlinked constituents are involved in this dynamic process: the scholarly discipline, the supervisor, the student, the institution (university or technical university with their peculiar academic cultures) 
and society. However, in this article the primary focus will be on the academic discipline because it lies at the heart of an academic culture and because those involved in the process of doctoral studies, the supervisor and the student, are the custodians and stewards of such a discipline. If this stewardship is properly executed non-academic society will also benefit from its contribution.

Golde and Walker describe a steward of a discipline as a person who 'thinks broadly about the entire span of the discipline and understands how its constituent parts fit together' (Golde \& Walker 2006:12). In this same volume Elkana points out that in the 'natural sciences' the doctorate is seemingly 'in a much better shape than are the much-debated doctorates in the social sciences and the humanities.' The emphasis on the word seemingly is connected to the view that apparently the natural sciences are 'much less controversial' than they were and their 'objectives are less often questioned' than they had been, because 'the scientific community indulges in a greater sense of consensus than is the case in the professional communities in other areas of academe' (Elkana 2006). Yet, on the same page she continues:

Elsewhere in this volume, Catharine Stimpson tells us that the humanities are messy, pointing out the double sense of their messiness: turmoil, disorder on the one hand, and healthy complexity on the other. The same is true about the natural sciences. Just as in the humanities and the social sciences, there are no complete theories of anything in the sciences: the theoretical structures are far from complete; the foundations abound in internal contradictions and rapidly changing presuppositions. But whereas the social sciences and the humanities accept incompleteness and contradiction as a given, perhaps even welcome it, most of the natural sciences ignore it, claiming that incompleteness and the accompanying contradictions do not affect the daily work of the scientist, neither in experimental work nor in theoretical deliberations, for they are considered unimportant passing phenomena-actually, mere noises-on the long and uninterrupted road toward certain and complete knowledge and Truth. (p. 67)

One of the leading mathematicians of the 20th century, Hermann Weyl, who switched from the axiomatic formalist school of David Hilbert and became a follower of the intuitionist, Brouwer, without hesitation confessed: 'Like everybody and everything in the world today, we have our 'crisis.' We have had it for nearly fifty years. Outwardly it does not seem to hamper our daily work, and yet I for one confess that it has had a considerable practical influence on my mathematical life: it directed my interests to fields I considered relatively 'safe,' and has been a constant drain on the enthusiasm and determination with which I pursued my research work' (Weyl 1966:13).

These remarks are sufficient to show that the long-standing admiration of 'universal reason' did not succeed in avoiding diverging schools of thought ('paradigms') within the scholarly disciplines. At the same time it underscores the need for a sound academic culture supporting the doctorate student to come to terms with diverging paradigms.

However, it should be kept in mind that the acquisition of postgraduate academic qualifications explores one important detour towards the development from childhood to maturity. It is normally accomplished by advancing the establishment and expansion of scholarly knowledge practically relevant for all walks of life, and it pre-supposes the remarkable correlation between two unique phases within the ontogenetic growth pattern of human beings - something, for the first time, investigated by the Swiss biologist, Adolf Portmann.

His empirical research is guided by the awareness of the fact that we are not certain about the phylogenies biologists talk about, but that we do have certainty about the natural system of currently living things. Instead of searching for similarities, Portmann rather investigates the differences between human beings and non-human living entities. According to this approach he characterises animals as Umweltgebunden [constrained by environment] and Instinktgesichert [protected by instinct] (Portmann 1990:79). In comparison with typical animal growth rhythms - which are gradual and continuous - the human growth rhythm displays two rapids, which are highlighted by a relatively long youth period running parallel with an accompanying long adult phase. These concurrent phases facilitate the effective educational transmission of a cultural legacy of millennia.

Portmann's pioneering work in this field established that human beings cannot be pigeonholed in either of the two developmental types that one finds in the realm of animals (animal kingdom - Nesthocker and Nestflüchter), ${ }_{1}$ which caused him to characterise human beings as follows: '... human behavior may be termed open to the world [Weltoffen] and possessed of freedom of choice' (Portmann 1990:79).

This biotic developmental dynamic therefore shows that each period of development must be seen as fully embedded within the characteristic human form of life. Within the context of a differentiated human society this form of life also embraces educational and learning institutions like schools and universities. Within the latter supervising postgraduate work occupies a modest but indispensible role in the continuation of our shared cultural legacy.

This article sets out to investigate some elements that ought to play a role in supervision within the context of the elements mentioned above. The significance of supervision will be situated within the requirements of a sound academic culture. Hence, we commence by looking at the importance of such an academic culture for supervision on the doctoral level. ${ }^{2}$

1.These Nesthocker (nest-huggers) and Nestflüchter (nest-leavers) are categorised in terms of independent criteria. The latter are animals which have a way of movement, stature and proportions at birth similar to their adult form, with open eyelids and hearing channels and little dependency on the parents. Nesthocker, on the other hand, are born in helpless dependence, with closed eyes and ears and dependent on care in a prepared nest. Where does the human being fit in? The human being is born with open eyes and ears - a Nestflüchter feature; the size and shape of its bodily parts are disproportional to the mature form - a Nesthocker feature; it has a long period of pregnancy - a Nestflüchter feature; it is helpless and dependent upon a prepared nest - a Nesthocker feature; its brain size increases with a factor of more than 5 - a Nestflüchter feature (the brain of the Nesthocker with a factor of more than $5-$ a Nestfluchter feature (the brain of the Nesthocker increases from birth to maturity with a factor of less than 5), and so on. The human being thus fits both and none of these two ontogenetic categories of Nestflüchter and Nesthocker - it represents a truly unique ontogenetic developmental pattern,
found nowhere else amongst non-human living entities.

2.A brief characterisation of the similarities and differences between a Master's dissertation and a PhD thesis is found in Lategan et al. (2005:74) 


\section{Probing the spirit of our academic dispensation}

A comprehensive understanding of the scholarly enterprise has to account for diverse and dominant scientific traditions within all the academic disciplines, embracing both the natural sciences and the humanities. Particularly during the 20th century an increasing awareness of the foundational role of theoretical frameworks ('paradigms') emerged eventually covered by the umbrella expression 'philosophy of science.'

In particular, supervising $\mathrm{PhD}$ studies therefore ought to take foundational issues into account, because at this level scholarly maturity requires that the implicit starting-point of such doctoral studies must be made explicit. This requirement applies even if the actual study is not primarily directed at this field of the philosophy of science (i.e. the philosophical foundations of the discipline). For this reason, reaching the highest qualification within any academic discipline, ought to articulate one or another theoretical view of reality in confrontation with competing theoretical frameworks or paradigms.

Lesham rightly points at foundational questions, such as: 'What are the boundaries of your investigation?' and 'How would you explain your conceptual framework?' (Lesham 2007:288).

Any prospective doctoral student has to obtain a familiarity with the dominating paradigms of the discipline in which such a student is working. The first obstacle encountered when this task is undertaken presents itself in a quite familiar term, the word 'science.' In North America and Britain, in particular, it is customary to restrict science to the domain of physics. What is normally not realised is that this practice mainly derives from a particular philosophical tradition, known as positivism, ${ }^{3}$ although its roots go back to the Renaissance and the rise of the modern era.

According to positivism, science proper is based upon socalled empirical observation, and experimentation - and for this reason it is objective and neutral. What is meant by empirical observation is that true science has to start from what could be experienced through the senses, that is, it proceeds on the basis of sensory perception and so-called sense data. From sense data, science is supposed to construe its concepts and derive its laws. What became known as the scientific method consisted in formulating hypotheses and in testing them (experimentally) in order to arrive at hypotheses which were supposed to turn into theories once they had been successfully 'verified' (eventually it was said that they were to be 'confirmed'). Given this strict delimitation of science there was a need to contemplate what falls outside this domain, in other words a demarcation problem emerged. Wallner phrases this issue as follows: 'It was always attempted anew to set limits to science, in order not to give up what is typically human' (Wallner 1992:63)

3.Positivism is also called logical-empirism, dominant in the philosophy of science during a large part of the 20th century.
Although this formulation of the problem may sound extremely innocent, its historical roots testify to the contrary. Going back to Immanuel Kant, the influential 18th century Enlightenment philosopher, opens a view on an intellectual tradition in which the rational capacities of the human being were highly regarded and eventually became triumphant in a rationalistic thought climate, such as the one found in the 18th century. In fact the underlying motivation of what surfaced within this Enlightenment era cannot be understood apart from the intellectual history of the preceding centuries. Initiated by the Renaissance, modern philosophy, during the 14th and 15th centuries, witnessed the rise of the ideal of an all-encompassing natural science (mathematics and physics) on the one hand, and the ideal of an autonomously free human person on the other.

Since Descartes (1596-1650), the ideal of such an encompassing natural scientific control of all reality started to dominate the scene. In order to proclaim its autonomy (being a law unto itself), and through this its freedom, the human person had to master reality with the aid of the newly developing natural sciences. In this way what became known as the personality ideal gave rise to the science-ideal.

In the mould of this new spiritual climate, the 'world' no longer embraces the human being. Rather, the world is now recovered as an object which is subject to the control of the autonomously free rational human being with its alldetermining natural scientific abilities. Husserl (1856-1938) refers to this as the rationalistic science ideal since Galileo (Husserl 1954:64ff., 119), and Dooyeweerd, in a similar fashion, speaks of the modern humanistic science ideal in its opposition to the humanistic personality ideal (nature versus freedom). The basic motive of modern Humanism is indeed that of nature (science ideal) and freedom (personality ideal) (cf. Dooyeweerd 1997-II:215ff.).

Because this is the motive directing our Western intellectual culture during the past 500 years, it is important that every supervisor and every doctoral student, in whatever discipline, has a basic understanding of the way in which this dialectical motive developed. This understanding should commence with the rationalism of Descartes, and follow its path until the long-standing rationalistic tradition is replaced by the irrationalism and relativism of postmodernity. Probing the way in which this dialectic permeated the various academic disciplines (both the natural sciences and the humanities) will enhance the intellectual level of the debate.

\section{Reductionism}

The striking shared feature of the developing academic disciplines is that both the natural sciences and the humanities were constantly characterised by diverging theoretical orientations, including mathematics, ${ }^{4}$ physics and

4.In respect of mathematics Beth remarks: "It is clear that intuitionistic mathematics is not merely that part of classical mathematics which would remain if one removed certain methods not acceptable to the intuitionists. On the contrary, intuitionistic certain methods not acceptable to the intuitionists. On the contrary, intuitionistic
mathematics replaces those methods by other ones that lead to results which find mathematics replaces those methods by other ones that
no counterpart in classical mathematics' (Beth 1965:89). 
even derived (or: applied) disciplines, such as engineering ${ }^{5}$ and medicine $\left.{ }^{6}\right)$. The founder of modern (20th century) intuitionism, L.E.J. Brouwer (1964), spells out this 'difference in standpoint' with unambiguous clarity:

As a matter of course the languages of the two mathematical schools also diverge. And even in those mathematical theories which are covered by a neutral language, that is by a language understandable on both sides, each school operates with mathematical entities not recognized by the other one: there are intuitionist structures which cannot be fitted into any classical logical frame, and there are classical arguments not applicable to any introspective image. Likewise, in the theories mentioned, mathematical entities recognized by both parties on each side are found to contain satisfying theorems which for the other school are either false, or senseless, or even in a way contradictory. In particular, theorems based in intuitionism, but not in classical mathematics, often originate from the circumstance that for mathematical entities belonging to a certain species, the possession of a certain property imposes a special character on their way of development from the basic intuition, and that from this special character of their way of development from the basic intuition, properties ensue which for classical mathematics are false. A striking example is the intuitionist theorem that a full function of the unity continuum, that is a function assigning a real number to every non-negative real number not exceeding unity, is necessarily uniformly continuous. (p. 79)

This factual state of affairs fundamentally challenges the positivistic ideal of objectivity and neutrality. Moreover, these philosophically founded schools of thought within the disciplines are more often than not entangled in what should be labelled reductionism in a pejorative sense. Popper is unambiguous in his rejection of reductionism. Consistent with his view he holds: 'As a philosophy, reductionism is a failure' (Popper 1974:269). Goodfield (1974) gives a balanced assessment:

Reductionist methodology may have been extremely successful, but the history of science abounds with examples where forms of explanation, successful in one field, have turned out to be disastrous when imported into another. (p. 86)

A positive appreciation of reduction is, for example, found in the thought of Dawkins and Dennett (see Dennet 1995:80 ff). Surely there are also positive and largely unrelated connotations attached to the term reduction in different special sciences. For example, mathematicians may speak of the construction of numbers from sets and then designate it as 'reduction'. Separating chemical compounds into their simpler constituents is also known as 'reduction', and so on. We shall see that the idea of irreducibility precludes every

5.The most prominent negative influence on engineering is found in the pervasive force of technicism in modern Western society. The well-known Dutch philosophe of technology, Egbert Schuurman, analyses the nature and shortcomings of technicism surrounding modern technology (Schuurman 1993, 1995, 2005 \& 2009).

6.A reductionist anatomical view of the human spine, linking it to our supposed quadruped ancestors, is an example of a medical practice in the grip of reductionism. Richard William Porter, who was the Director of Education and Training for the Roya Richard William Porter, who was the Director of Education and Training for the Roya College of Surgeons of Edinburgh, was mainly interested in spine and osteoporosis research (he is the author of many books and over 100 peer-reviewed articles). One of his merits is that he highlighted the fact that the assumed 'early' quadruped phase of human beings led to therapeutic practices for reducing lordosis which worsened the problem. Sarfati concludes: 'Evolutionary notions of bad design in the human spine have impeded the development of appropriate treatments for injured backs' (Sarfati 2010:282). reductionist approach. The only meaningful option is to investigate the interconnections of what is irreducible. The challenge to all scholarship is to understand the coherence of irreducibles - or more strongly formulated: to understand in terms of the coherence of irreducibles! Whoever wants to avoid the reduction of what is irreducible opts for what ought to be designated as a non-reductionist ontology. ${ }^{7}$

In order to capture more problematic situations the term reductionism had emerged by the middle of the 20th century. In 1953 Quine used it in his discussion of 'The Verification Theory and Reductionism' (see Quine 1953:37ff) and in the early seventies the work 'Beyond Reductionism' appeared (see Koestler \& Smythies 1972). In this work, Smith considers the scientist-philosopher Michael Polanyi to be 'perhaps the severest and most comprehensive critic of reductionism' because he 'was a major scientist of this century and was drawn into philosophical debate primarily because of the threat to scientific freedom, political democracy, and to humane values that he saw in reductionism.' To this Smith (1994) adds the remark:

His works The Contempt of Freedom, The Logic of Liberty, Science Faith and Society, Personal Knowledge, and The Tacit Dimension have as a common theme the criticism of reductionism in all its scientific, cultural and moral forms. (n.p.)

Compare the remarks of G.L. Smith, 'On Reductionism.' Putnam holds that scientism and relativism are reductionist theories (Putnam 1982:126). In respect of 'phenomenalism' he remarks:

the idea that the statements of science are translatable one by one into statements about what experiences we will have if we perform certain actions has now been given up as an unacceptable kind of reductionism. (Putnam 1982:187)

\section{Logical validity and truth}

From an epistemological perspective another intrinsic consideration supports a non-reductionist approach. Logic as such, in its concern for the validity of arguments, has to accept the logical principles of identity and non-contradiction. However, these two principles merely enable one to realise that two contradictory statements cannot both be true in the same logical context. In order to establish the truth of a statement other logical principles are needed, first of all the principle of the excluded middle. ${ }^{9}$

It is generally accepted that the validity of an argument ought to be distinguished from its truth. This convinced many scholars that there is a world of 'pure thinking,' stripped of any connections with the 'outer world.' Both predicate logic and propositional (formal) logic seem to operate only on the

7.Be therefore aware of the difference between 'reduction' and 'reductionism', that is the absolutisation of reduction. Reduction is a valid and fruitful scientific method (e.g., the rendering of physical states of affairs in mathematical terms). Reductionism believes that explanation consists of reduction only. See the reference to the view of Margenau below.

\section{See also Heitler (1972:60).}

9.This principle concerns the case where the totality of what can be analysed is divided such that any statement either belongs to the one or the other part - there is no third option (Latin: tertium non datur). Already Aristotle understood the principle of the excluded middle (see Metaph. 1057a - see Aristotle 2001:845-846). 
basis of the logical principles of identity, (non-)contradiction and the excluded middle. For example, if one looks at the deductive syllogism in its four modes, whilst considering that there are four kinds of propositions involved - universal affirmative [A] and universal negative [E]; particular affirmative [I] and particular negative [O] - and then asks two questions:

1. how many inference patterns are there?

2. how many of these constitute valid inferences? - then it is clear that, of the 256 possibilities, only a limited number are valid (p. 21).

In order to differentiate between valid and invalid inferences, an implicit or explicit use of the logical principles of identity and non-contradiction is required. Only on this basis is it possible to evaluate a particular inference as being logically sound or illogical. But this constitutes a normative contrary - only human beings with an accountably free will are able to act in conformity with logical principles or violate such principles. Also, the domain of propositional logic presupposes the said logical principles.

The entire distinction between subject and predicate - in its logical sense - is dependent upon the nature of concepts. Predicates normally explicate (logically identified and distinguished) traits brought together in the unity of a concept. Any property which is excluded from this logical unity of the concept cannot be predicated of it afterwards, except in an illogical way. If it were true that the concept '(material) body' excludes the property of weight [mass] to begin with - as Immanuel Kant asserts in his Critique of Pure Reason (1787, B:10ff) - then the so-called 'synthetic' proposition: 'all bodies are heavy' would be illogical because it violates the principle of non-contradiction. ${ }^{10}$

\section{Nuanced theories}

The claim that reductionism is unwarranted implicitly presupposes the conviction that 'irreducibles' and 'primitives' exist. Typical (reductionist) all-claims, such as that everything is number (the Pythagoreans), or everything is interpretation (postmodernism), challenge the idea of uniqueness and irreducibility. All-claims like these are mainly monistic in nature - in the sense that they want to find one single, all-encompassing perspective or principle of explanation capable of accounting for the entire diversity manifest in our experience of the universe. With reference to Einstein's thirty-year search for a unified field theory, Brian Greene, a specialist in the theory of Super Strings, for example, believes that physicists will find (have found) a framework fitting their insights into a 'seamless whole,' a 'single theory that, in principle, is capable of describing all phenomena' (Greene 2003:viii). He introduces Super String theory as the 'Unified Theory of Everything' (Greene 2003:15; see also pp. 364-370, 385-386).

A mere look at the terms used in Greene's claim shows that its formulation exceeds the confines of a purely physical

10.It is therefore significant that the prominent German logicians of the 19th century eventually turned this proposition into an 'analytic' statement (Lotze, Windelband, Sigwart). perspective. Any physical theory, for that matter, is inevitably dependent upon non-physical terms - an insight that applies to all the academic disciplines. In Greene's remark the wholeparts relation features - he speaks of a 'seamless whole.' However, this relation finds its original 'seat' within the spatial aspect, for the core meaning of space - continuous extension - entails that in order to be continuous all the extended parts must be connected in the sense of cohering with each other. Yet, when all the parts are given, the whole is given as well, showing that continuous extension is simply synonymous with the whole-parts relation (see Strauss, 2009a:40ff; \& Strauss 2009b:60-61, 224-225, 239-240, 353-355, 306-307, 406-408).

But perhaps the best argument in support of a non-reductionist ontology flows from the universal presence of primitive terms in all disciplines. Semantics, as a sub-discipline of general linguistics, had to accept 'meaning' as such as a primitive term. Similarly axiomatic set theory also had to accept primitive terms. For example, within Zermelo-Fraenkel set theory, 'member of ${ }^{\prime 11}$ is introduced as a primitive term - and Gödel once remarked that as yet we do not have a satisfactory non-circular definition of the term set. ${ }^{12}$ Within set theory the primitive meaning of both number and space is therefore quite evident, for the multiplicity (number) of 'members' which are considered to be united into a whole. Our remark above, namely that continuous extension is synonymous to the whole-parts relation and the notion of coherence, is supported by a statement from Shapiro: 'coherence is not a rigorously defined mathematical notion, and there is no noncircular way to characterize it' (Shapiro 2000:13).

The acknowledgement of 'primitive terms' in connection with uniqueness and coherence highlights one element of the mentioned problem regarding the coherence of irreducibles. Gödel understood this issue in his own way. Yourgrau explains that he 'insisted that to know the primitive concepts, one must not only understand their relationships to the other primitives but must grasp them on their own, by a kind of 'intuition' (Yourgrau 2005:169). On the next page he adds that 'the fundamental concepts are primitive and their meaning is not exhausted by their relationships to other concepts.'

An argument in favour of the acknowledgement of irreducibility - as one side of the coin (with the mutual coherence of what is unique as the other side) - ought to show that an unwarranted reductionism is entangled in unsolved problems (normally referred to as contradictions, paradoxes or antinomies). We mentioned that Margenau defended a 'moderate reductionism' by pursuing the strategy consisting of reducing whatever can be reduced, without however

11.See also the remark of Penelope, where she points out that within first order logic membership $(\varepsilon)$ is 'its only non-logical symbol' (Penelope 2000:50). Whereas mathematical logic needs something non-logical, we have noted that likewise any physical theory is also in need of non-physical terms.

12.'The operation 'set of $x^{\prime} s^{\prime}$ (where the variable ' $x$ ' ranges over some given kind of objects) cannot be defined satisfactorily (at least not in the present state of knowledge), but can only be paraphrased by other expressions involving again the concept of set, such as: 'multitude of $x^{\prime} s^{\prime}$, 'combination of any number of $x^{\prime} s^{\prime}$ ', 'part of the totality of $x^{\prime} s^{\prime}$ ', where a 'multitude' ('combination', 'part') is conceived as of the totality of $x^{\prime} s^{\prime}$, where a 'multitude ('combination', 'part') is conceived as
something that exists in itself, no matter whether or not we can define it in a finite number of words (so that random sets are not excluded)' (Gödel 1964:262). 
ignoring emergence or persisting in reducing the irreducible (cf. Margenau 1982:187, 196-197).

Ernst Cassirer, the philosopher from the neo-Kantian Marburg school (perhaps best known for his three volume work Philosophy of Symbolic Forms), is also explicit in this regard when he claims that a critical analysis of knowledge, in order to avoid a regressus in infinitum, has to accept certain basic functions that are not capable of being 'deduced' and not in need of a deduction (see Cassirer 1957:73).

This insight enabled us to connect the inevitable employment of such basic (and irreducible) concepts to the indefinable meaning-nuclei of the different (irreducible) modal aspects. Precisely because these concepts are basic, they cannot be defined straight away. Various disciplines acknowledge this state of affairs by explicitly introducing 'primitive terms.'

The inevitability of primitive terms, in their connection with the issue of the 'coherence of irreducibles,' at once also entails a fundamental criticism of the positivist program attempting to reduce knowledge to sense-data.

The implication of the issue regarding the coherence of irreducibles underscores the importance for research within all the disciplines not to fall short of an acknowledgement of the radical diversity within reality and a nuanced theoretical account of this diversity. At the same time it liberates us from the out-dated positivistic philosophy.

\section{The impasse of positivism}

What positivism did not realise is that sensory perception primarily relates to things and events, that is to say, to the concrete what of experience, but that it does not give access to the (primitive) terms employed in describing the how of what has been observed. These terms, to be sure, stem from the various functional (modal) aspects of reality and these modal functions, as such, are never open to sensory perception. Nonetheless these aspects do provide theoretical thinking with modal terms (aspectual terms) that are indispensable for the formation of scientific concepts and theories. As soon as the inevitability of employing modal terms is acknowledged, the Achilles' heel of positivism is laid bare (see Strauss 2003). For example, the history of the concept of matter successively explored different modes of explanation - starting with the perspective of number and then proceeding to the aspect of space, the kinematic aspect and eventually the physical aspect of reality. The key question is whether or not these modal aspects could be observed in a sensory way. Can they be weighed, touched, measured or smelled? (see Strauss 2006a). Heitler refers to the Schrödinger wave-function which, according to him, cannot be observed in its mathematical existence, even though it is the instrument through which assertions about observable properties can be made (Heitler 1972:62).

We may add that in the formation of physical theories, it is never the case that a particular theoretical statement, as such, is confronted directly with a single sensory experience. The above-mentioned formidable mathematician, Hermann Weyl, subscribes to the conception of Hugo Dingler in viewing physical theories in terms of what is called the principle of symbolical construction. Weyl (1966) holds the following view:

[That the] constructive character of the natural sciences, the situation that their individual propositions do not have a verifiable meaning in intuition (Anschauung), but that truth builds a system which can only as a whole be assessed. (p. 192)

Max Planck states a similar perspective in a concise way: Strictly seen it is totally impossible to find any physical question which can be assessed directly through measurements without the aid of a theory (Planck 1973:341).

Although Popper is sometimes associated with positivism, he considers himself a major figure in causing the death of positivism. One of his main concerns was also the problem of demarcation, given in the question: is it possible to elevate the isolated domain of 'science' to be the sole source of reliable knowledge of reality, or is it rather the case that even science, as such, is dependent upon assumptions that cannot be 'verified' by science itself? As it turned out, this question intimately coheres with the problem of induction (i.e. the nature of generalisations): is it possible to obtain knowledge with a claim to universality merely by investigating a limited number of instances?

Hacohen points out that Popper 'sought to overcome the gap the Wiener Kreis had opened between science and philosophy' (Hacohen 2002:195). By attempting this, Popper once again opened the avenue to historical perspectives, because there is no single discipline (special science) which does not, in one or another way, mirror within its own confines the successive trends manifested in the history of philosophy. At the same time these trends of thought are themselves interrelated in a twofold way. First of all they share an appeal to certain states of affairs within reality, and secondly they all respond, albeit in different ways, to these states of affairs.

\section{Persistent themes and scientific revolutions}

Suppose we consider the definition of any special science and then scrutinise it in terms of the difference between what is (ontically) given and how we responded to it. Theology is sometimes considered to consist of different groups of subjects, such as the dogmatological, ecclesiological, and bibliological groups. Yet identifying these groups of academic sub-disciplines does not clearly say what is studied by theology - it rather tells us something about the (sub-) disciplines involved in studying whatever it may be. Likewise, if one says that mathematics is set theory or is constituted by algebra and topology, merely the 'response-side' surfaces whilst the persistent, underlying ontic side is neglected. If we define a discipline in terms of what is currently practiced by those who are working within the discipline, our definition 
is, by definition, historically dated. Surely, it is meaningless to say that Greek mathematics or Fermat, Bernoulli or Cauchy researched set theory. Therefore, in terms of the definition that mathematics is set theory, these thinkers were not mathematicians.

The alternative is to account for those aspects of reality delimiting the field of investigation of the various academic disciplines. Then it is quite easy to realise that mathematics, for example, has been concerned with the nature of number and space since its very inception (or discreteness and continuity). ${ }^{13}$ Likewise, in spite of different theoretical stances in respect of material things throughout the history of physics, the varying historical theories never succeeded in moving away from the kinematic and physical aspects of reality.

By combining the focus of Kuhn (1970) on scientific revolutions with Holton's emphasis on persistent themes, it becomes easier to maintain both perspectives at once - and this should be a challenge to the supervisor and doctoral student within every academic discipline. However, Holton points out that 'for every thematic informed theory used in any science there may also be found a theory using the opposite thema, or antithema'. Holton (1988) mentions the current search for:

'the constituents of 'elementary particles' ... a pursuit that has made sense to scientists all the way back to Thales. It is nothing less than an a priori commitment that deserves to be called thematic' (p. 14)

It is clear that the underlying ontic conditions at stake are different from an a priori thematic commitment. What is actually required is discerning the ontic features of reality making possible all kinds of thematic commitments.

In the case of the mathematical meaning of number and space - always associated with our awareness of the primitive meaning of discreteness and continuity - it should indeed be understood that the ontic conditions making possible theoretical approaches in which it is attempted either to explain physical reality (matter) exclusively in terms of discreteness ('particles') or purely in terms of continuity (field theories), are not the product of theoretical reflection. It is clear that this distinction between atomism and continuity is based upon number and space as the two most basic modes of explanation of reality. In the attempt to understand matter, according to Stegmüller, also other unique modes of explanation surfaced (Stegmüller 1987):

1. the apparent indestructibility of matter.

2. the apparent or real limitless transformability of matter. (p. 91)

These two points highlight a theme known since early Greek philosophy - the relationship between constancy and change. Holton (1988) writes:

Since Parmenides and Heraclitus, the members of the thematic dyad of constancy and change have vied their loyalty, and

13.'Bridging the gap between the domains of discreteness and continuity, or between arithmetic and geometry, is a central, 'presumably even the central problem of the foundations of mathematics (Fraenkel et al. 1973:211). to have, even since, Pythagoras and Thales, the efficacy of mathematics versus the efficacy of materialistic or mechanistic models. (p. 17)

When these last-mentioned problems are assessed in their coherence, it is immediately clear that they depend upon the third and fourth ontic modes of explanation in reality, namely the meaning of kinematic persistence ('immutability') and physical changefulness ('transformability').

Persistent themes are imbedded within scholarly paradigms or theoretical views of reality, sometimes also designated as conceptual frameworks. ${ }^{14}$ Although explaining in sufficient detail what is really entailed in a theoretical framework exceeds the scope of this article, it should be noted that the complexity and reach of such a theoretical paradigm should encompass not only the elementary basic concepts of a discipline, but also the compound and typical concepts. ${ }^{15}$ The remark quoted by Lesham, namely that in a workshop students had 'to define' their conceptual frameworks 'in a single sentence' (Lesham 2007:292) does reflect a fairly reduced understanding of the nature of a theoretical framework. A much better account of these issues is found in two publications made available under the editorship of Lategan (see Lategan \& Lues, 2005 \& Lategan, Hey, Holtzhausen, Truscott, \& Vermeulen 2005). In these works a clear understanding of what is advocated in this article is found, even though more detailed arguments are currently advanced. Our aim is to take these issues a step further. The current literature within the field of higher education may benefit from the thrust of our current analyses because as such they are not articulated within it.

\section{The aims of science}

In his work of the foundation of physics Stafleu (1980) discerns seven aims of scientific endeavours:

1. the explication of laws

2. the reduction and deduction of laws

3. abstraction or analysis

4. reconstruction or synthesis of typical laws ${ }^{16}$

5. identifying modal aspects (modes of explanation and relatedness) and exploring their backward and forward point connections with other aspects

6. objectification

7. explaining individual facts and phenomena. (pp. 8-29)

In the light of the foregoing considerations regarding theoretical views of reality - in their relation to the coherence of what is unique, and the other issues pertaining to a non-

14. Because the significant Report, The PhD Study, An Evidence-based Study on how to meet the Demands of High-level Skills in an Emerging Economy (Jonathan 2010) does not explicitly enter into an analysis of the role of theoretical paradigms on the doctoral level, our current suggestions should be seen as aimed at furthe exploring the starting-points provided in this Report. In the Report itself the word paradigm and the phrase conceptual framework are both just briefly mentioned (twice, to be precise).

15.Compare Strauss 2006a:125-270.

16.'Whereas typical laws can usually be found by induction and generalisation of empirical facts or lower level law statements, modal laws are found by abstraction. Euclidean geometry, Galileo's discovery of the laws of motion ... and thermodynamic laws are all examples of laws found by abstraction. This state of affairs is reflected in the use of the term 'rational mechanics,' in distinction from affairs is reflected in the use of the term '
experimental physics' (Stafleu 1980:11). 
reductionist ontology - the task and role of a supervisor is not simple at all. The positivistic ideal of the objectivity and neutrality of scholarly activities is currently out-dated - this is also the case within the domain of mathematics. Consider the title of a book written by Kline (1980): Mathematics, The Loss of Certainty, and note that the mathematician Hersh also questions the supposed infallibility and objectivity of mathematics (see Hersh 1997, Part One, Chapter 3, pp. 35-47).

\section{Argumentative skills}

Within the process of supervising it is fundamental that the student should implement argumentative skills. An acquaintance with informal logic is basic. Suppose, for example, an academic concerned about crime and the legal system in South Africa makes the following statement in a class: 'You are all too bright to reject capital punishment!'

This statement first of all appeals to the intelligence (being 'bright') of the students without putting forward an argument either in favour or against capital punishment (within informal logic this is called an argument ad hominem). In the second place it refers to a widely held negative attitude towards not applying capital punishment without justifying this negative attitude [argumentum ad invidiam]. The third fallacy is seen in the attempt to persuade the students on the basis of flattery - crediting them with the quality of being 'bright,' once again without advancing any positive or negative argument for or against capital punishment [argumentum ad captandum]. Finally the statement contains a variant of the ad populum fallacy (directed towards a general sentiment, empathy or fear), in this case specifically directed towards the personal fear of students who may be afraid of being seen as non-intelligent by their lecturer or fellow students [argumentum ad baculum]. ${ }^{17}$

Furthermore, one of the popular slogans of contemporary academic institutions is found in the idea that scholars (lecturers and students) ought to be critical. This ideal of critical thinking is uncritically repeated in many contexts uncritically because one is never informed about the criteria that are to be applied whilst engaging in 'critical thinking'!

We have observed that two contradictory statements cannot both be true at the same time and in the same circumstances. However, in order to decide which one is true logic as such falls short. That truth is more than merely a logical issue was for the first time clearly seen by Leibniz in his formulation of the principium rationis sufficientis. This refers thinking beyond the limits of pure logicality. Ultimately all the mentioned logical principles rest on the basis of the ontic principle of the excluded antinomy. The latter principle brings to expression the irreducibility of what is unique - entailing that whenever an attempt is made to reduce any modal aspect to a different one, theoretical thought will inevitably be caught up in insurmountable antinomies.

17.The habit of saying that we have many choices confuses choice with options: we normally have many options, but just one choice at a time.
Therefore the logical principle of non-contradiction is founded in this underlying ontic principle, namely the principle that forbids reducing one modal aspect to another one (see Dooyeweerd 1997-II: 36 ff.). This principle is ontic in nature and should be called the principium exclusae antinomiae. The above-mentioned perennial philosophical problem of explaining the coherence of what is unique and irreducible (the coherence of irreducibles) therefore opens the way to an acknowledgment of the foundational position of the principium exclusae antinomiae in respect of the logical principle of non-contradiction - and at once explains why the distinction between antinomy and contradiction is not purely logical in nature. The principium exclusae antinomiae not only depicts the limits of logic, but also underscores the significance of a non-reductionist ontology transcending the confines of logic. Ontological reductionism violates the principium exclusae antinomiae and it leads to disastrous consequences, entailing all kinds of logical contradictions. Even if we disregard possible underlying antinomies, a negation of the principle of non-contradiction is equally devastating. Hersh remarks: 'From any contradiction, all propositions (and their negations) follow! Everything's both true and false! The theory collapses in ruins' (Hersh 1997:31).

Zeno's argument: 'Something moving neither moves in the space it occupies, nor in the space it does not occupy' (Diels \& Kranz 1959-1960, B Fr.3), is antinomic. It concerns a clash of irreducible laws. When a moving body is, at every moment of its 'movement,' in one specific place, it appears to be at rest, because 'being in one place' simply means 'not being in motion. ${ }^{18}$ An antinomy emerges as soon as theoretical thought confuses what is ontically unique and irreducible. The attempt to explain movement in terms of space therefore results in a (theoretical) conflict between kinematic laws of motion and spatial laws. Stafleu suggests that one way to interpret Zeno's arguments 'against' motion is that he in fact demonstrates that motion cannot be explained by numerical and spatial relations (see Stafleu 1987:61). The same applies to the classical school in economics which attempted to reduce economic life to a physical equilibrium, as if economic life is governed by natural laws instead of economic principles, making possible the contrary: economic - un-economic. ${ }^{19}$ The possibility of conforming to or contradicting principles, that is to say, to act in norm-violating or norm-conformative ways, presupposes an accountable will with freedom of choice. It should therefore not be surprising that the naturalistic assumptions of Darwinism are spelled out explicitly by Dawkins (1996) when he categorically assumes an antinomic position that opposes any form of normed accountablity:

$\ldots$ if the universe were just electrons and selfish genes, ..., $[I t]$ would manifest no intentions of any kind. In a universe of blind physical forces and genetic replication ... [S] uch a universe would be neither evil nor good. ... The universe we observe has

18. However, in a letter to Moritz Schlick (07 June 1920) Einstein writes: 'Rest is a dynamic event in which the velocities are constantly zero, one that for our consideration is, in principle, equivalent to any other event of motion' (Einstein 2006:186).

19.Within the discipline of economics Milton Friedman and Von Hayek are well-known defenders of the classical school of Adam Smith and the free-market capitalism entailed by it. It was superseded by the neoclassical approach (from Cournot and Dupuit to Menger, Jevons, Walras and Pareto), the marginalism of Marshall and Keynes's 'General Theory' as well as alternative approaches to competition (Chamberlin and Robinson). 
precisely the properties we should expect if there is, at bottom, no design, no purpose, no evil and no good, nothing but blind, pitiless indifference. (p. 155)

In this sense antinomies therefore concern an inter-modal confusion, that is, a lack of distinguishing properly between different modes, functions or aspects of reality. The illogical concept of a square circle merely confuses two spatial figures - residing within the spatial aspect. A contradiction like this is intra-modal and therefore different from an antinomy which is inter-modal in nature.

The alternative to (antinomic) reductionism is given in an analysis of inter-modal connections presupposing their irreducibility. One of the richest implications enclosed in such an analysis is the fact that it is possible to come to a theoretical articulation of modal norms on the basis of analysing analogies (retro and anticipations) on the norm side of the normative aspects of reality.

\section{Scientific communication and 'facts'}

One of the main challenges for supervision is to educate scholars to be able to communicate effectively with alternative and even opposing points of view. At the most basic level this involves the presence of informal fallacies. Then one may exercise immanent criticism by looking at internal inconsistencies (contradictions) by bringing into play the logical principle of non-contradiction and, if applicable, the principle of the excluded middle. Subsequently, a scientific position may be tested by applying the principle of sufficient reason (ground), which may lead to the exercise of factual criticism. Only after this has been accomplished is it meaningful to formulate an alternative point of view, for otherwise, that is, without factual and immanent criticism, a scholarly interaction (discussion) easily terminates in the proverbial: 'I say this and you say that, so what?'

It should be kept in mind, however, that the philosophy of science during the 20th century transcended the positivistic notion of 'brute facts.' Facts are structured, they occur within an ontic order - for this reason an arithmetical fact $(2+2=4)$ differs from a geometrical fact $(\underline{2}+\underline{2}=\sqrt{8}-$ it represents a vector sum), and so on. Because scholarship employs a theoretical framework in order to account for factual states of affairs even observation is said to be 'theory-laden.'

Look for example at the expectation Darwin (1859) had concerning 'numerous, fine, intermediate varieties' breaking 'down the distinction between species':

Geological research, ..., yet has done scarcely anything in breaking down the distinction between species, by connecting them together by numerous, fine, intermediate varieties; and this not having been affected, is probably the greatest and most obvious of all the many objections which may be urged against my views. (p. 307)

However, with reference to invertebrate animals, Dawkins (1987) says:

And we find many of them already in an advanced state of evolution the very first time they appear. It is though they were just planted there, without any evolutionary history. (p. 229)
Stark refers to Gould: 'The extreme rarity of transitional forms in the fossil record (the professional secret of paleontologists) is the most prominent problem for Darwinism' (quoted by Van den Beukel 2005:105). According to Gould and Eldredge (1977) stasis (constancy) is the dominant pattern in paleontology:

The extreme rarity of transitional forms in the fossil record persists as the trade secret of paleontology. The evolutionary trees that adorn our textbooks have data only at the tips and nodes of their branches; the rest is inference, however reasonable, not evidence of fossils. (p. 14)

More recently Gould (2002) states:

The fossil record may, after all, be 99 percent imperfect, but if you can, nonetheless, sample a species at a large number of horizons well spread over several million years, and if these samples record no net change, with beginning and end points substantially the same, and with only mild and errant fluctuation among the numerous collections in between, then a conclusion of stasis rests on the presence of data, not on absence! In such cases, we must limit our lament about imperfection to a wry observation that nature, rather than human design, has established a sampling scheme by providing only occasional snapshots over a full interval. We might have preferred a more even temporal spacing of these snapshots, but so long as our samples span the temporal range of a species, with reasonable representation throughout, why grouse at nature's failure to match optimal experimental design - when she has, in fact, been very kind to us in supplying abundant information. Stasis is data. (p. 759)

When a 'gradualist' has to account for a new fossil, the Darwinian prejudice will position it in a line of slow, incremental change even though there are not fossils available to substantiate this interpretation. Gould, by contrast, will appreciate such a finding in terms of the dominant pattern of the fossil record: stasis.

\section{On the same page Gould (2002) continues:}

So if stasis could not be explained away as missing information, how could gradualism face this most prominent signal from the fossil record? The most negative of all strategies - a quite unconscious conspiracy of silence - dictated the canonical response of paleontologists to their observations of stasis. Again, a 'culprit' may be identified in the ineluctable embedding of observation within theory. (p. 759)

And then he makes a statement regarding facts which shows that he has 'digested' the thrust of the philosophy of science of the second half of the 20th century (Kuhn, Feyerabend, Lakatos, Stegmüller, Toulmin and others):

Facts have no independent existence in science, or in any human endeavor; theories grant differing weights, values, and descriptions, even to the most empirical and undeniable of observations. Darwin's expectations defined evolution as gradual change. Generations of paleontologists learned to equate the potential documentation of evolution with the discovery of insensible intermediacy in a sequence of fossils. In this context, stasis can only record sorrow and disappointment. (Gould 2002:759)

By contrast, within the tradition of reformational philosophy stasis is acknowledged and seen as pointing towards the order-diversity within creation - appreciated as being informed by the biblical life view. 


\section{The significance of an articulated academic culture for universities and society}

From the preceding considerations regarding the development of an articulated academic culture, it follows that a supervisor may consider its efforts significant if the doctoral student following this supervision masters all the skills, insights and strategies briefly alluded to above. It will serve the personal career of the student and it will explore the potential and possibilities of the student at the same time.

The university as an academic institution may benefit by investing more in the career of such a student in the spirit of 'growing your own timber.' A student participating in a well-grounded academic culture will be intellectually mature enough to handle the challenges of life, either within or outside the academia, with intellectual honesty and accountability.

We may summarise the key elements of my plea for establishing an academic culture at universities as follows (focused on the role of supervision). The supervisor should at least succeed in achieving the following goals:

- To create an awareness amongst doctoral students regarding the diverse paradigms within the discipline in question (paradigms in the sense of an unavoidable theoretical view of reality).

- To obtain a brief overview of the modern era since the Renaissance, including the significance of the Enlightenment (the 18th century as the era of conceptual rationalism), the historicism of the 19th century and the linguistic turn of the 20th century.

- To be sensitive to manifestations of the nature-freedom dialectic permeating all academic disciplines since the Renaissance.

- To understand why positivism as a reductionist philosophy of science is currently outdated.

- To know the difference between logical validity and scientific truth, supported by the insight that through the principle of sufficient reason (ground) scientific thinking is pointed beyond logic to the ontic grounds upon which truth claims can be articulated.

- To account for primitive terms and the issue of irreducibility and, thus, respond to the perennial philosophical problem of the coherence of irreducibles found in all academic disciplines.

- To realise that understanding and concept-formation always proceed from basic indefinable terms, explaining why defining cannot go on ad infinitum.

- To realise that a theoretical framework is much more comprehensive than something that could be summarised in a single paragraph.

- To appreciate both the elements of continuity and discontinuity within scholarly theories, also known as persistent themes and scientific revolutions.

- To be able to question the problematic and mistaken idea that certain sciences are 'exact' - with reference to examples from the natural sciences.
- To master argumentative skills - at least those found and discussed in informal logic.

- To understand the nature of scholarly communication and in particular the status of 'facts' without the various academic disciplines. [The example given in this context focused on the (neo)Darwinian belief in gradualism (with its apriori philosophical assumption regarding continuous transitions) and the reality of discontinuity (found in the fossil record and the currently living world), characterised by Stephan Gould as stasis (constancy).]

Between the lines of these goals one may discern the necessity and importance of more explicit education in the field of philosophy of science because, without an understanding of the philosophical foundations of the various academic disciplines, supervision on the doctoral level may become a victim of one or another scientific paradigm, instead of selfcritically and consciously accounting for the theoretical view of reality from which both the supervisor and the doctoral student proceed (and it does not necessarily need to be the same paradigm!).

\section{Acknowledgements Competing interests}

The author declares that he has no financial or personal relationships which may have inappropriately influenced him in writing this article.

\section{References}

Aristotle, 2001, 'The Basic Works of Aristotle', in R. McKeon (ed.), with an Introduction by C.D.C. Reeve, The Modern Library, New York.

Beth, E., 1965, Mathematical Thought, D. Reidel, Dordrecht.

Brouwer, L.E.J., 1964, 'Consciousness, Philosophy, and Mathematics', in P. Benacerraf \& H. Putnam (eds.), pp.78-84, Philosophy of Mathematics, Selected Readings, Basil Blackwell, Oxford.

Cassirer, E., 1957, Das Erkenntnisproblem in der Philosophie und Wissenschaft der neueren Zeit, Kohlhammer Verlag, Stuttgart.

Darwin, C., 1859, 'On the Origin of Species by Means of Natural Selection or the Preservation of favoured races in the struggle for life', with an Introduction by J.W. Burrow (ed.), 1968, Penguin Books, Harmondsworth.

Dawkins, R., 1987, The Blind Watchmaker, W.W. Norton Co., New York.

Dawkins, R., 1996, River out of Eden, Phoenix, London.

Dennet, D.C., 1995, Darwin's Dangerous Idea. Evolution and the Meanings of Life, Touchstone, New York.

Diels, H. \& Kranz, W., 1959-1960, Die Fragmente der Vorsokratiker, vols. I-III. Weidmannsche Verlagsbuchhandlung, Berlin.

Dooyeweerd, H., 1997, A New Critique of Theoretical Thought, in D.F.M. Strauss (gen ed.), Collected Works of Herman Dooyeweerd, A Series vols. I-IV, Edwin Mellen, Lewiston.
Lewister.

Einstein, A., 2006, The Collected Papers of Albert Einstein, vol. 10, tranls. A. Hentschel, University Press, Princeton.

Elkana, Y., 2006, 'Unmasking Uncertainties and Embracing Contradictions: Graduate Education in the Sciences', in G.M. Golde \& G.E. Walker (eds.), Envisioning the Future of Doctoral Education. Preparing Stewards of the Discipline, pp. 65-96 Carnegie Essays on the Doctorate, Jossey-bass, San Francisco.

Fraenkel, A., Bar-hillel, Y., Levy, A. \& Van Dalen, D., 1973, Foundations of Set Theory, 2nd rev. edn., North Holland, Amsterdam.

Gödel, K., 1964, 'What is Cantor's Continuum Problem?' in P. Benacerraf \& H. Putnam (eds.), Philosophy of Mathematics, Basil Blackwell, Oxford.

Golde, C.M. \& Walker, G.E., 2006, Envisioning the Future of Doctoral Education. Preparing Stewards of the Discipline, Carnegie Essays on the Doctorate, Josseybass, San Francisco.

Goodfield, J., 1974, 'Changing Strategies: A Comparison of Reductionist Attitudes in Biological and Medical Research in the Nineteenth and Twentieth Centuries', in T. Dobzhansky \& F.J. Ayala (eds.), Studies in the Philosophy of Biology. Reduction and Related Problems, pp. 65-86, University of California Press, Berkeley.

Gould, S.J. \& Eldredge, N., 1977 'Evolution's Erratic Pace', in Natural History 86, 5. 
Gould, S.J., 2002, The Structure of Evolutionary Theory, Harvard University Press, Cambridge.

Greene, B., 2003, The Elegant Universe, W.W. Norton \& Company Inc., New York.

Hacohen, M.H., 2002, Karl Popper, The Formative Years 1902-1945, University Press, Cambridge.

Heitler, W., 1972, Wahrheit und Richtrigkeit in den exakten Wissenschaften, in Abhandlungen der mathematisch-naturwissenschaftlichen Klasse Jahrgang 1972(3) pp. 45-64.

Hersh, R., 1997, What is Mathemtics Really?, Oxford University Press, Oxford.

Holton, G., 1988, Thematic Origins of Scientific Thought, Kepler to Einstein, Harvard University Press, Cambridge.

Husserl, E., 1954, Die Krisis der europäischen Wissenschaften und die Transzendentale Phänomenologie, Husserliana Band VI, Martinus Nijhoff, The Hague.

Jonathan, J. (Chair), 2010, The PhD Study, An Evidence-based Study on how to meet the Demands of High-level Skills in an Emerging Economy, viewed 18 July 2011, from http://www.assaf.org.za/wp-content/uploads/2010/10/40696-BoldesignPHD-small-optimised.pdf

Kant, I., 1787, Kritik der reinen Vernunft, 2nd edn. (references to CPR B - 1956), Felix Meiner, Hamburg.

Kline, M., 1980, Mathematics, the loss of certainty, Oxford University Press, New York Koestler, A. \& Smythies, J.R. (eds.), 1972, Beyond Reductionism, Macmillan, New York.

Kuhn, T., 1970, The Structure of Scientific Revolutions, 2nd rev. edn., The University Press of Chicago, Chicago.

Lategan, L.O.K. \& Lues, L. (eds.), 2005, Doing Research. Bloemfontein, Tekskor.

Lategan, L.O.K., Hey, D., Holtzhausen, S., Truscott, M., \& Vermeulen, W., 2005, in L.O.K. Lategan \& L. Lues (eds.), Doing Research, pp. 64-78, Tekskor, Bloemfontein.

Lesham, S., 2007, 'Thinking about conceptional frameworks in a research community of practice: A case of a doctoral programme', in Innovations in Education and Teaching International 44(3), pp. 287-299.

Margenau, H., 1982, 'Physics and the Doctrine of Reductionism', in J. Agassi \& R.S. Cohen (eds.), Scientific Philosophy Today, Essays in Honour of Mario Bunge, Boston Studies in the Philosophy of Science, vol. 67, pp. 187-199, Reidel, Dordrecht.

Penelope, M., 2000, Naturalism in Mathematics, University Press, Oxford.

Planck, M., 1973, Vorträge und Erinnerungen, 5th edn., Wissenschaftliche Buchgesellschaft, Darmstadt.

Popper, K.R., 1974, 'Scientific Reduction and the Essential Incompleteness of Al Science', in T. Dobzhansky, \& F.J. Ayala (eds.), Studies in the Philosophy of Biology. Reduction and Related Problems, pp. 259-284, University of California Press, Berkeley.

Portmann, A., 1990, A zoologist looks at humankind, transl. J. Schaefer, Columbia University Press, New York.

Putnam, H., 1982, Reason, Truth and History, Cambridge University Press, Cambridge, MA.

Quine, W.V.O., 1953, From a logical point of view, Harvard University Press, Cambridge MA.
Sarfati, J., 2010, The Greatest Hoax on Earth? Refuting Dawkins on Evolution, Creation Book Publishers, Atlanta.

Schuurman, E., 1993, 'Techniek, Technologie en het Technisch Wereldbeeld', in H.A Van der der Ploeg, M.H.J. Dulhaart \& A.E. Vlug (reds.), Tastend Zien, Opstellen in dankbare herinnering opgedragen aan dr. F. De Graaff, pp. 191-206, Merweboek, Sliedrecht.

Schuurman, E., 1995, Perspectives on Technology and Culture, Dordt College Press, Sioux Center.

Schuurman, E., 2005, The Technological World Picture and the Ethics of Responsibility, Struggles in the Ethics of Technology, Dordt College Press, Dordt.

Schuurman, E., 2009, Technology and the Future, 2nd edn., Paideia Press, Jordan Station.

Shapiro, S., 2000, Philosophy of Mathematics, Structure and Ontology, Oxford University Press, Oxford.

Smith, G.L., 1994, On Reductionism. Sewanee, Tennessee, viewed 22 January 2005, from http://smith2.sewanee.edu/texts/Ecology/OnReductionism.htm

Stafleu, M.D., 1980, Time and Again, A Systematic Analysis of the Foundations of Physics, Wedge, Toronto.

Stafleu, M.D., 1987, Theories at Work: On the Structure and Functioning of Theories in Science, in Particular during the Copernican Revolution, University Press of America, Lanham.

Stegmüller, W., 1987, Hauptströmungen der Gegenwartsphilosophie, vol. III, Alfred Kröner Verlag, Stuttgart.

Strauss, D.F.M., 2003, 'The Achilles' heel of positivism', Koers - Bulletin for Christian Scholarship 68(2\&3), 255-278.

Strauss, D.F.M., 2006a, Reintegrating Social Theory - Reflecting upon human society and the discipline of sociology, Peter Lang, Frankfurt am Main.

Strauss, D.F.M., 2006b, 'Filosofiese tendense in die wordingsgeskiedenis van on verstaan van die fisiese natuur', Akademie Tydskrif vir Natuurwetenskappe 25(2), 93-110.

Strauss, D.F.M., 2009a, 'The Significance of a Non-Reductionist Ontology for The Discipline of Mathematics: A Historical and Systematic Analysis', Axiomathes: An International Journal in Ontology and Cognitive Systems 20, 19-52.

Strauss, D.F.M., 2009b, Philosophy: Discipline of the Disciplines, Paideia Press, Grand Rapids.

Van den Beukel, A., 2005, 'Darwinisme: wetenschap en/of ideologie?', in C. Dekker, R. Meester \& R. Van Woudenberg (eds.), Schitterend Ongeluk of Sporen van Ontwerp? pp. 101-116, Ten Have, Kampen.

Wallner, F., 1992, Acht Vorlesungen über den Konstruktiven Realismus, WUV Universitätsverlag, Vienna.

Weyl, H., 1966, Philosophie der Mathematik und Naturwissenschaft, 3rd revised and expanded edn., R. Oldenburg, Vienna.

Yourgrau, P., 2005, A World Without Time. The forgotten Legacy of Gödel and Einstein, Penguin Books, London. 